\title{
RITUAL RAMBUT GEMBEL DALAM ARUS EKSPANSI PASAR PARIWISATA
}

\author{
Moh. Soehadha \\ UIN Sunan Kalijaga Yogyakarta \\ e-mail: suhadhaa@yahoo.co.id
}

\begin{abstract}
This article focusing on religious and social change in Dieng tourism society and its relation with state capitalism. The government has commercialize gembel hair ritual (ritual rambut gembel) by tourism policy, that long have been live in Dieng community. In this article indicated that there are two variants of the social response to the change, the people who accept and reject society. The receiving society is the people that having an interest in economic on activities of the tourism development, whereas the rejecter society is the people that hold belief and tradition faithful. Theoretically, this study gives an explanation that public religiosity into the value system which affect people's behavior to confirm the mode of economic production runs, as well as oversee social change.

$* * *$

Tulisan ini mengambil fokus pada agama dan perubahan sosial akibat ekspansi pasar pariwisata di dataran tinggi Dieng, dan hubungannya dengan kapitalisme negara. Pemerintah telah mengusahakan ritual rambut gembel sebagai komoditas pariwisata di dataran tinggi Dieng. Hasil analisis menunjukkan bahwa ada dua varian respon sosial terhadap perubahan akibat ekspansi pasar pariwisata, yaitu masyarakat yang menerima dan masyarakat yang menolak. Masyarakat penerima adalah orang-orang yang memiliki kepentingan di bidang ekonomi dalam kegiatan pengembangan pariwisata, sedangkan masyarakat yang menolak adalah orang-orang yang memegang keyakinan dan tradisi lokal. Secara teoritis, studi ini memberi penjelasan bahwa religiusitas masyarakat dipengaruhi oleh moda produksi ekonomi yang ada.
\end{abstract}

Keywords: rambutgembel, tradisi lokal, religiusitas, pariwisata, produksi ekonomi 


\section{A. Pendahuluan}

"Cerak Watu Adoh Ratu" (dekat batu, jauh dari kekuasaan), demikian ungkapan Jawa yang sering menjadi label untuk membedakan antara kehidupan Wong Gunung (orang dataran tinggi) dengan Wong Ngare (orang kota). Akan halnya dengan orang Dieng, sebutan wong nggunung juga masih sering dilekatkan oleh masyarakat di wilayah dataran rendah atau perkotaan terhadap mereka, hanya lantaran mereka tinggal di wilayah dataran tinggi, meskipun kehidupan orang Dieng masa kini telah "mengkota".

Dieng dikenal sebagai wilayah dataran tinggi yang berhawa dingin dan menjadi salah satu kawasan wisata di Jawa Tengah. Secara historis, sejak abad VII M sebelum masuknya agama Islam, Dieng masa lalu merupakan salah satu pusat peradaban Hindu. Masyarakat Dieng pada waktu itu menganut agama Hindu, pada masa Kerajaan Mataram Kuno. Keberadaan situs Candi Arjuna menjadi salah satu bukti, bahwa pada abad VII kawasan Dieng merupakan salah satu pusat perkembangan Hindu Jawa. Setelah masuknya pengaruh Islam yang di bawa oleh para wali di Jawa, maka secara berangsur masyarakat Dieng menganut Islam.

Kendati masyarakat Dieng telah menganut Islam, namun religiusitas masyarakat, terutama praktik ritual yang bernuansa Hindu masih sangat kental. Salah satu ritual bernuansa Hindu yang masih dilaksanakan masyarakat adalah ritual ruwatan anak berambut gembel (gimbal). Dalam keyakinan masyarakat Dieng, tumbuhnya rambut gembel pada anak-anak di Dieng dianggap sebagai penyakit yang hanya dialami oleh penduduk di sekitar dataran tinggi Dieng. Dengan demikian, ritual ruwatan rambut gembel ini secara antropologis merupakan fenomena budaya yang unik, sebab hanya ditemukan pada masyarakat uplander atau dataran tinggi Dieng.

Terdapat dua pendapat yang berbeda tentang penyebab terjadinya rambut gembel menurut penafsiran masyarakat setempat. Sebagian masyarakat percaya bahwa tumbuhnya rambut gembel pada anak-anak Dieng disebabkan oleh pengaruh makhluk halus yang merasuki jiwa si anak. Anak-anak berambut gimbal dianggap sebagai anak-anak yang masih ada dalam kekuasaan roh penunggu kawasan Dieng, yaitu Tumenggung Kolo Dete. Adapun sebagian masyarakat yang lain menganggap bahwa penyebab tumbuhnya rambut gembel yang diderita anak-anak, disebabkan oleh pe- 
ngaruh cuaca atau gejala alam, dan kebiasaan masyarakat yang tidak terbiasa menyisir rambut.

Terlepas dari varian tafsiran tersebut, masyarakat Dieng cenderung masih melakukan ritual ruwatan rambut gembel. Praktek ritual ruwatan rambut gembel inilah yang teridentifikasi sebagai kekhasan pola religuisitas masyarakat uplander Dieng. Religiusitas dalam hal ini dipahami sebagai gambaran perilaku keagamaan masyarakat uplander yang dipengaruhi oleh kebudayaan Hindu. Oleh Geertz (1960), gambaran tentang religiusitas masyarakat Muslim yang bernuansa Hindu dan Kejawen ini disebutnya sebagai religiusitas abangan. Dalam analisisnya, Geertz menghubungkan struktur sosial dari mekanisme pasar di kota yang rasional dengan implementasi ajaran Islam yang lebih murni yang disebutnya sebagai masyarakat santri. Ia juga menghubungkan struktur sosial dari mekanisme pertanian di desa dengan implentasi ajaran Islam yang bercampur dengan nilai-nilai lokal yang dipertahankan sejak sebelum masuknya Islam.

Islam yang berkembang di wilayah Dieng pada mulanya merupakan Islam fenomena kota, hal ini berkaitan erat dengan aktivitas penyebaran Islam yang banyak dibawa oleh para pedagang. Walaupun demikian pengamalan ajaran Islam di Dieng bukan merupakan kelanjutan ajaran Islam murni di kota, melainkan satu tahap perubahan karena faktor dari luar. Dalam hal ini religiusitas masyarakat Dieng menjadi unik, karena perubahan sosial yang terus terjadi di wilayah itu, terutama akibat masuknya pengaruh komoditas pertanian yang gayut (terkait) dengan ekonomi pasar dan pariwisata.

Dilihat dari aspek sosio ekonominya, pada dasawarsa 1900 sampai akhir 1980-an Dieng adalah sebuah kawasan penghasil tembakau. ${ }^{1}$ Seiring dengan perubahan waktu, jenis pertanian di Dieng mengalami peralihan lagi dari tanaman tembakau menjadi kentang. Peralihan tanaman yang terjadi di kawasan Dieng dapat dikaitkan dengan program revolusi hijau (green revolution) tahun 1970 . Pemerintah pada waktu itu berupaya mengenalkan tanaman yang tumbuh lebih cepat, dan secara potensial dapat memberikan hasil yang lebih tinggi. Tentunya hal ini didukung oleh penggunaan pupuk

1 Murray Tania Li, Proses Transformasi Daerah Pedalaman di Indonesia, (Jakarta: Yayasan Obor Indonesia, 2002), h. 93. 
kimiawi dan pertisida secara besar-besaran. ${ }^{2}$ Kini masyarakat Dieng mengalami kemajuan ekonomi dari hasil pembudidayaan tanaman kentang yang berorientasi pasar.

Pada sisi lain, perubahan juga terjadi karena program pariwisata yang dicanangkan pemerintah. Situs candi Hindu di kawasan Dieng menjadi daya tarik wisatawan untuk berkunjung ke Dieng, sehingga pemerintah terus menata kawasan tersebut sebagai salah satu tujuan wisata yang dianggap dapat menjadi sumber pendapatan pemerintah daerah. Kapitalisasi Dieng melalui pariwisata menyebabkan perubahan gaya hidup masyarakat setempat. Pada konteks inilah, masyarakat Dieng dengan kekhasan ritualnya tengah dihadapkan pada dua arus besar perubahan. Pertama adalah ekspansi kiri berupa kekuatan pasar atas nama pengembangan pariwisata, dan kedua adalah ekspansi kanan dalam hal ini negara melalui kebijakan pemerintah yang gayut terhadap pasar. Sehingga dapat diasumsikan bahwa ritual rambut gembel yang semula berwajah keyakinan, secara berangsur berubah wajah menjadi komoditas an sich. Dari asumsi tentang praktek ritual rambut gembel masyarakat Dieng yang berada di antara kekuatan pasar dan kapitalisasi pemerintah tersebut, menimbulkan problematik ilmiah tentang pengaruh ekspansi pasar pariwisata dan kapitalisasi pemerintah terhadap eksistensi religiusitas masyarakat uplander Dieng.

\section{B. Asumsi Teoritis}

Dalam perspektif materialisme sejarah diasumsikan bahwa religiusitas adalah sistem nilai yang mempengaruhi perilaku dan dijunjung oleh masyarakat untuk mengukuhkan moda produksi (ekonomi) yang berjalan, dan mengawal perubahan sosial. ${ }^{3}$ Religi menjadi mode of thought, sistem gagasan dalam merespon, menerima, menolak, atau proses tarik-ulur (adaptasi) masyarakat terhadap arus perubahan. Religi menjadi kekuatan dinamis dalam mengawal perubahan sosial.

Dengan perspektif perubahan sosial dan kaitannya dengan religiusitas tersebut, maka analisis atas faktor dominan yang mempengaruhi perubahan

2 Robert W. Hefner, Geger Tengger Perubahan Sosial dan Perkelahian Politik, (Yogyakarta: LkiS, 1999), h. 133.

3 "Seperangkat praktek dan teknologi yang digunakan untuk memperluas atau membatasi produksi kebutuhan hidupyang mendasar" (Harris, 1979: 52). 
sosial yang terjadi, dapat dimulai dengan menganalisis ritual lokal masyarakat Dieng, yaitu ritual ruwatan rambut gembel. Dengan mengikuti pengertian yang diberikan oleh Turner (1966: 19), ritual diartikan sebagai perilaku tertentu yang bersifat formal, dilakukan dalam waktu tertentu secara berkala, bukan sekedar sebagai rutinitas yang bersifat teknis, melainkan menunjuk pada tindakan yang didasari oleh keyakinan religius terhadap kekuasaan atau kekuatan-kekuatan mistis.

Mengacu pada pengertian yang telah diberikan oleh Turner tersebut, maka pada hakikatnya kajian yang ditekankan pada sistem ritual bukan berarti mengabaikan sistem ajaran yang menjadi landasan keyakinan para penganut sistem religi tertentu. Sebab sebagai suatu sistem, ritual tidak dapat dipisahkan dengan doktrin, praktek ritual selalu dilandasi oleh doktrin yang telah diyakini oleh para pengikutnya. Pentingnya aspek ritual bagi para pengkaji yang ingin mempelajari makna agama antara lain dikemukakan oleh Clifford Geertz (1968; 1992), ${ }^{4}$ menurutnya, untuk mencapai hakikat dari tindakan religius, maka pandangan analitis harus sampai kepada ritual.

Pentingnya analisis terhadap ritual dalam mengkaji perubahan dilandasi oleh asumsi bahwa perubahan sosial adalah fakta sosial yang di dalamnya individu akan mengikuti bentuk kesepakatan bersama tentang fakta sosial baru, karena individu tidak bisa berdiri sendiri, dan akan menggantungkan pada norma yang berlaku dalam masyarakat, yang semuanya itu tercermin dari perfoma ritual. Sebab perubahan sosial pada hakikatnya adalah alih rupa atau adaptasi pranata sosial, termasuk didalamnya nilai-nilai, sikap dan pola perilaku di antara kelompok dalam masyarakat.

Gagasan untuk mengkaji ritual dalam konteks perubahan sosial Dieng, juga dilandasi asumsi bahwa dalam ritual, secara jelas tergambar arus kekuatan pasar dan kapitalisasi negara. Melalui ritual lokal dapat dianalisis

\footnotetext{
${ }^{4}$ Pentingnya aspek ritual bagi para peneliti yang ingin mengkaji agama juga dikemukakan oleh A.R Radcliffe-Brown (1980) dan Dhavamony (1995). Menurut Radcliffe-Brown (1980: 117) untuk belajar agama pertama-tama harus ditumpukan pada ritual, bukan pada kepercayaan (iman). Sebab upacara merupakan unsur yang paling stabil dan kekal. Sementara itu menurut Dhavamony (1995: 167), pentingnya ritual bagi pengamatan ilmiah karena ritual merupakan agama dalam tindakan. Tindakan agama terutama ditampakkan dalam ritual. Meski ungkapan iman merupakan bagian dari ritual atau bahkan ritual itu sendiri, namun iman keagamaan pada dasarnya berusaha menjelaskan makna dari ritual serta memberikan tafsiran dan mengarahkan vitalitas dari pelaksanakan ritual tersebut.
} 
tingkat kesadaran masyarakat dalam merespon perubahan. Terjadi dialektika yang saling menentukan antara basis ekonomi dan superstruktur ideologi dan kesadaran. Kebudayaan dan ideologi mempengaruhi opsi-opsi, dan individu-individu menyeleksi masing-masing pilihan untuk bertindak.

Hasil analisis tentang ritual itu dapat membawa jalan dalam memberikan kategori kesadaran masyarakat yang terbagi dua, yaitu masyarakat pasif dan masyarakat aktif. Masyarakat pasif yaitu masyarakat dimana para anggotanya mudah bahkan sepenuhnya dikendalikan oleh kekuatan-kekuatan luar. Sementara masyarakat aktif adalah masyarakat yang para anggotanya memiliki kesadaran untuk dapat mengubah hukum-hukum sosial. Pada konteks kesadaran masyarakat aktif itulah, sesungguhnya individu memiliki posisi sebagai pencipta yang dapat mengutak-atik, membentuk dan menanggulangi segala kebutuhannya. Etzioni ${ }^{5}$ menggarisbawahi tiga komponen penting sebagai ciri khas atau orientasi masyarakat aktif yaitu kesadaran warga (individu), pengetahuan dan komitmen pada satu atau lebih tujuan yang harus dicapai dan memiliki kewenangan (fasilitas kekuasaan) untuk mengubah tatanan sosial. Kendati demikian, hal penting yang tidak boleh dilupakan adalah setiap kesadaran yang diejawantahkan bukan tanpa berbagai kendala sebab setiap aksi sosial bisa dipastikan menimbulkan kontra aksi.

\section{Kondisi Alam dan Islam Kawasan Dataran Tinggi Dieng}

Dataran Tinggi Dieng (DTD) adalah wilayah vulkanik aktif dan dapat dikatakan merupakan gunung api raksasa. Kawah-kawah kepundan banyak dijumpai di sana. Ketinggian rata-rata adalah sekitar 2.000 meter di atas permukaan laut. Suhu di Dieng sejuk mendekati dingin, berkisar $15-20^{\circ} \mathrm{C}$ di siang hari dan $10^{\circ} \mathrm{C}$ di malam hari. Pada musim kemarau, suhu udara terkadang dapat mencapai $0^{\circ} \mathrm{C}$ di pagi hari dan memunculkan embun beku yang oleh penduduk setempat disebut bun upas ("embun racun") karena menyebabkan kerusakan pada tanaman pertanian.

Dataran setinggi 2000 meter di atas permukaan laut ini tidak hanya memiliki pesona alam yang elok, tetapi juga menyimpan segundang misteri tentang peradaban manusia sejak ratusan tahun silam. Bangunan berbentuk

${ }^{5}$ Amitai Etzioni, The Active Society, (New York: The Free Press, 1968). 
candi yang masih berdiri kokoh di dataran Dieng merupakan saksi bisu bahwa di tempat ini telah hadir suatu komunitas sosial pemeluk Hindu. Candi-candi di dataran tinggi Dieng diperkirakan sudah mulai di bangun pada abad ke VIII M di zaman keemasan Dinasti Kalingga dan baru selesai pada abad XIII M. Di zaman Wangsa Syailendra. ${ }^{6}$ Candi yang dibangun sebagai tempat pemujaan dewa Siwa ini, juga dipercaya sebagai tempat pertemuan para dewa yang turun dari kahyangan, di candi ini juga konon para dewa berinteraksi langsung dengan para pemujanya.

Kehadiran candi-candi ini pula yang menyebabkan dataran tinggi ini disebut Dieng; yang berasal dari kata Adi yang berarti tinggi dan Hyang yang berarti suci dan luhur, sehingga Dieng bisa diartikan tempat bersemayamnya para leluhur yang suci. ${ }^{7}$ Candi-candi tersebut kemudian diberi nama tokohtokoh dalam kisah Mahabarata seperti: Candi Arjuna, Candi Srikandi, Candi Kuntadewa, Candi Sembadra, Candi Bima dan Candi Gatotkaca. Bangunan candi-candi di Dieng disusun dari batu jenis andeshif. Batu-batu tersebut berasal dari gunung Pakuaja, yaitu sebuah gunung yang berada di sebelah selatan kompleks candi.

Dataran tinggi Dieng terbentuk oleh amblesnya sebagian dari gunung tua yaitu Gunung Perahu, oleh patahan yang berarah dari barat laut dan tenggara. Pada bagian yang ambes itu muncul gunung-gunung kecil yang tersebar di kawasan Dieng seperti; Gunung Alam, Gunung Nagasari, Gunung Panglimunan, Gunung Pangonan, Gunung Gajah Mungkur dan Gunung Pakuaja. Sampai sekarang gunung api di dataran tinggi Dieng mempunyai karakteristik yang khas yaitu tekanan magma yang terkandung di dalamnya tidak terlalu kuat. Oleh sebab itu, sampai sekarang di pegunungan Dieng tidak terjadi letusan aktif seperti yang terjadi di Gunung Merapi. Jikapun terjadi letusan, hal itu disebabkan terpanaskannya air bawah tanah oleh magma.

Di kawasan Dieng terdapat banyak kawah. Di antaranya adalah kawah Sikidang, di kawah ini terdapat lumpur mendidih dengan bau belerang yang

\footnotetext{
${ }^{6}$ Dokumen Stasiun TV SCTV, “Potret”, Episode: MisteriSi Rambut Gimbal, Copy Right. 2006

7 Dokumentasi Film Teater Dieng Plateu, versi yang lain menyebutkan nama Dieng berasal dari gabungan dua kata bahasa Sunda Kuna: "di" yang berarti "tempat" atau "gunung" dan "Hyang" yang bermakna (Dewa). Dengan demikian, Dieng berarti daerah pegunungan tempat para dewa dan dewi bersemayam. Nama Dieng berasal dari bahasa Sunda karena diperkirakan pada masa praMedang 600 daerah itu berada dalam pengaruh politik Kerajaan Galuh. Selasa, 6 Oktober 2009.
} 
sangat menyengat, gejala ini disebabkan karena terpanaskannya air oleh magma di dalam perut bumi. Di kawah lainnya yaitu kawah Candradimuka bisa ditemukan aktivitas vulkanik berupa uap panas dari dalam bumi dengan bau belerang yang pekat. Sumber air panas kawah ini disebabkan oleh tekanan gas. Kendati gas yang keluar dari kawah sikidang adalah gas yang mengandung $\mathrm{CO}_{2}$ yang tinggi, tetapi cukup aman di kunjungi karena tempatnya yang terbuka. ${ }^{8}$ Di antara kawah-kawah yang ada di dataran tinggi Dieng, kawah Timbang merupakan kawah yang paling banyak mengandung gas $\mathrm{CO}_{2}$. Keluarnya uapan gas di dalam bumi akibat tekanan gas yang kuat menerabas lapisan permukaan yang lemah atau melalui rekahan tanah akibat gempa bumi. $^{9}$

Tidak banyak tempat di Indonesia berhawa dan berpanorama seperti Dieng, karena ketinggiannya membuat hawa Dieng sangat sejuk, bahkan seputar Juli-Agustus menjelang mentari pagi di ufuk timur, udara bisa mencapai titik beku, embun yang menempel pada daun-daun menjadi kristal es. Tidak jauh dari gugusan kawah-kawah yang mengitari candi-candi di Dieng, ada suatu komunitas masyarakat yang unik, yang ciri-ciri fisiknya berbeda dengan orang kebanyakan. Mereka itulah anak-anak berambut gembel yang dianggap membawa pengaruh gaib. Kehadiran mereka tidak bisa dipisahkan dari mitos yang tumbuh subur di kawasan Dieng sejak tempo dulu hingga sekarang.

Untuk mengetahui perkembangan Islam di kawasan Dieng dapat ditelusuri dari keberadaan makam leluhur masyarakat setempat, yaitu makam Mbah Mangkuyuda dan Natayudha. Menurut penuturan beberapa tokoh setempat, Islam dibawa dan disebarkan oleh raden Mangkuyuda dan

8 Berada di tepi Telaga warna dan kawah ini sering memunculkan suara seperti suara alat musik Jawa yang disebut kendang atau genderang. Ini merupakan salah satu kawah dari sekian banyak kawah di kawasan dataran tinggi Dieng. Kawah Sikidang adalah kawah di dataran tinggi Dieng yang paling populer dikunjungi karena paling mudah dicapai. Kawah ini terkenal karena lubang keluarnya gas selalu berpindah-pindah di dalam suatu kawasan luas.

9 Terdapat banyak kawah sebagai tempat keluarnya gas, uap air dan berbagai material vulkanik lainnya. Keadaan ini sangat berbahaya bagi penduduk yang menghuni wilayah itu, terbukti dengan adanya bencana letusan gas Kawah Sinila 1979. Tidak hanya gas beracun, tetapi juga dapat dimungkinkan terjadi gempa bumi, letusan lumpur, tanah longsor dan banjir. Data diperoleh di Museum Dieng Kailasa, memberikan informas tentang artefak, alam (geologi, flora-fauna), masyarakat Dieng (keseharian, pertanian, kepercayaan, kesenian) serta warisan arkeologi dari Dieng. Selasa, 6 Oktober 2009. 
Natayudha, keturunan dari silsilah Prabu Brawijaya keV dari Majapahit. Ini di dukung juga dengan sumber informasi dari buku silsilah Poro Noto yang disusun G.R.Ay. Brata Diningrat (Kasunanan Surakarta).

Cara penyebaran Islam dikawasan Dieng yang dilakukan oleh Mbah Mangkuyuda serupa dengan yang dilakukan oleh wali dalam menyebarkan Islam di Jawa, di antaranya melalui seni tari dan gamelan. Di antara tarian yang digunakan dalam proses penyebaran Islam adalah tari Lengger, tari Siripiti, tari Ogeng-ogeng, dan tari Rangu-rangu. Masing-masing tarian tersebut memiliki tujuan untuk dakwah Islam. Tari lengger digunakan dalam upaya untuk mengumpulkan massa, adapun tari Siripiti digunakan untuk membiasakan jari dalam wiridan. Tari Oden-ogeng atau Ogeng-ogeng (sebutan tarian di desa Dieng Kulon) digunakan dalam melatih anggota badan untuk melakukan gerakan wudhu, sedangkan untuk gerakan shalat menggunakan tari Joko Raden atau dikenal di Dieng Kulan sebagai tari Rangurangu.

Berbagai bentuk kegitan pelestarian tarian tersebut bisa dijumpai di daerah Dieng Kulon. Tarian tersebut kini dilestarikan tidak hanya sebagai warisan budaya, tetapi juga sebagai daya tarik untuk wisatawan. Pertunjukan seni tari di Dieng Kulon biasanya dilaksanakan untuk menyambut para tamu dan wisatawan.

\section{Sejarah Wisata Dieng}

Sebagai kawasan yang kemudian dikembangkan sebagai objek pariwisata, potensi Dieng sebagai lumbung pendapatan daerah di Kabupaten Banjarnegara dan Wonosobo, keberadaannya tidak dapat dilepaskan dari penemuan pertama kali kawasan tersebut sebagai situs purbakala. Situs pemujaaan candi Hindu Dieng ditemukan pertamakali oleh sejarawan Belanda Flaber Van Hove pada awal abad ke-18. Pada masa itu situs candi masih dalam kondisi terendam air dan sulit dilakukan penggalian. Kemungkinan situs candi tersebut, dulu merupakan basin atau bekas kawah yang kemudian terendam air.

Penggalian situs baru dilakukan pada sekitar tahun 1840, yaitu ketika salah seorang ahli sejarah berkebangsaan Inggris menemukan saluran air 
untuk menyelamatkan situs candi di Dieng, yaitu dengan cara membersihkan air di sekitar kawasan candi. Setelah kemerdekaan, usaha untuk melakukan konservasi terhadap kawasan situs candi Dieng terus dilakukan oleh lembaga kepurbakalaan. Usaha tersebut tidak lepas dari perhatian pemerintah untuk melestarikan berbagai peninggalan peradaban masyarakat Indonesia di masa lalu. Meskipun situs candi di Dieng telah dikenal dunia sejak abad XVIII, namun sampai tahun 1990-an wilayah ini masih dianggap sebagai wilayah paling terpencil di Jawa Tengah.

Perkembangan sosial ekonomi dataran tinggi Dieng baru mulai nampak pada tahun 2000-an, terutama karena Dieng dikenal sebagai wilayah pertanian penghasil kentang, dan pusat penghasil energi listrik panas bumi. Di samping itu penataan situs candi Dieng yang terus menerus dilakukan oleh pemerintah, menjadi daya tarik tersendiri bagi orang luar untuk membuka keterisolasian Dieng di masa lalu. Pada masa kini, pelestarian situs Dieng tidak hanya dilakukan sebagai bagian dari usaha untuk mengabadikan peninggalan peradaban masa lalu, namun juga dikembangkan sebagai bagian dari upaya untuk mengembangkan pariwisata.

Upaya untuk mengembangkan kawasan Dieng sebagai objek wisata dilakukan pertama kali oleh Pemerintah Kabupaten Wonosobo pada tahun 1994. Oleh karena itu, meskipun kawasan wisata Dieng berada di dua wilayah Kabupaten, yaitu Banjarnegara dan Wonosobo, pada mulanya Dieng dikenal sebagai kawasan wisata milik Kabupaten Wonosobo. Setelah memasuki era otonomi daerah, pada tahun 2000 kawasan wisata Dieng kemudian dikelola secara bersama-sama oleh pemerintah Kabupaten Wonosobo dan Kabupaten Banjarnegara. Realisasi kerjasama antara dua wilayah kabupaten itu baru mulai terasa, terutama setelah dilakukan penandatanganan nota kesapahaman (MoU) antara dua wilayah kabupaten tersebut, pada hari kamis tanggal 1 Agustus 2002 di kompleks kawah Sikidang, dengan disaksikan oleh Gubernur Jawa Tengah, Mardiyanto.

Salah satu bentuk upaya pemerintah daerah setempat dalam mengembangkan wisata Dieng adalah dengan melakukan komodifikasi ritual rambut gembel. Kini ritual ruwatan anak berambut gembel telah berangsur pudar, namun keberadaannya mulai diangkat kembali oleh Dinas Pariwisata bekerjasama dengan salah satu organisasi penghayat Kepercayaan Kejawen 
di Kabupaten Wonosobo. Ruwatan rambut gembel dikembangkan kembali sebagai tradisi ritual dalam paket Gebyar Budaya Dieng untuk menambah pundi-pundi pendapatan Daerah melalui pariwisata.

\section{E. Eksistensi Ritual Rambut Gembel di tengah Ekspansi Pasar Pariwisata}

Fakta tentang keberadaan anak berambut gembel (gimbal) merupakan salah satu ciri khas masyarakat kawasan Dieng sejak ratusan tahun lalu. Warga Dieng percaya bahwa anak berambut gembel adalah anak-anak kesayangan roh gaib penunggu dataran Dieng yang mendapat titipan dari siluman penguasa laut selatan Nyai Roro Kidul. Pada saatnya nanti rambut gimbal yang melekat pada anak-anak Dieng dikenal juga dengan istilah (anakanak bajang) akan diminta kembali oleh sang Ratu Kidul. Itu sebabnya para orang tua sedapat mungkin akan menjaga dan mengistimewakan anaknya yang terkena rambut gembel, agar keluarganya terhindar dari segala bentuk malapetaka.

Harapan itu misalnya dapat digambarkan seperti yang dilakukan oleh pak Sukirno terhadap anak semata wayangnya Azizatun Hasanah. Azizah demikian panggilan akrab si anak, mulai berambut gimbal ketika mulai menginjak usia 2 tahun, kini di usianya yang sudah menginjak usia 5 tahunn, Azizah meminta orang tuanya untuk melaksanakan ruwatan potong rambut. Orangtuanya segera mengajak Azizah ke rumah seorang dukun Mbah Naryono ${ }^{10}$ yang secara kebetulan akan melaksanakan ruwatan massal bagi anak-anak berambut gimbal (anak-anak bajang). Pertama-tama sang dukun bertanya apa yang diinginkan oleh si anak sebelum rambut gimbal-nya di potong, Azizah yang yang polos memberi persyaratan sebelum dirinya diruwat dengan meminta orang tuanya menyediakan daging sapi goreng dan mie instan 10 bungkus. Dipandang ringan permintaan si anak, pak Sukirno mengabulkan permohonan Azizah. ${ }^{11}$

\footnotetext{
10 Menurut Mbah Naryono, pemangku adat Dieng ruwatan gimbal bertujuan membuang sesuker (sebel) orang tuanya.

11 Sebelum memotong rambut gimbal anak itu, permintaan si anak harus dipenuhi. Tidak jarang si anak gimbal itu sering meminta sesuatu yang di luar nalar anak sebayanya. Bahkan menurut cerita dari masyarakat sekitar, ada orang yang menjadi gila akibat permintaannya terlalu sulit untuk dipenuhi yaitu meminta ular sekendang (ular yang sebesar kendang).
} 
Sebagai bagian dari prosesi ruwat rambut gembel, masyarakat mempercayakan kepada Mbah Rusmanto sebagai sesepuh spritual sekaligus juru kunci kawasan dataran tinggi Dieng. Sebagai sesepuh spiritual Mbah Rusmanto wajib melakukan perjalanan spritual ke beberapa lokasi tempat para leluhur bersemayam. Salah satu tempat yang diyakini hingga kini sebagai tempat bersemayamnya para leluhur adalah Tuk Bimolukar. Tuk Bimolukar adalah sebuah mata air dengan pancuran yang terbuat dari batu purba, mata air ini juga diyakini sebagai sumber air dari Sungai Serayu. Nama Bimalukar berasal dari kisah bahwa Sang Bhima Sena melukar (melepas) pakaiannya untuk disucikan. Inilah mata air sungai Serayu yang cukup terkenal itu dan diyakini dapat menjadikan orang awet muda. Terlepas dari kepercayaan itu, di tempat inilah Mbah Rusmanto didampingi 3 orang mengawali ritual dengan memberi tahu kepada sang Mbahu-rekso Pangeran Bimo bahwa esok hari pihaknya akan mengadakan ruwatan bagi anak-anak berambut gimbal.

Usai melaksanakan prosesi pemberitahuan, Mbah Rusmanto dan para pendampingnya melanjutkan perjalanan spritual. Bukit demi bukit di dataran Dieng mereka daki, lembah demi lembah mereka arungi, ini merupakan napak tilas spritual sebagai penghormatan kepada leluhur yang pernah diyakini pernah hidup di tanah dataran Dieng. ${ }^{12}$ Setibanya di puncak Gunung Kendil, Mbah Rusmanto menghaturkan caos dahar kepada penguasa roh leluhur Kyai Tumenggung Kolo Dete dan Istrinya Nyai Laras Cinde yang mokhsa saat bertapa. ${ }^{13}$ Kyai Kolo Dete adalah pemimpin roh ghaib yang menghuni dataran Dieng yang dititipi anak gimbal oleh Nyai Roro Kidul. Mbah Rusmanto memohon agar riual potong rambut gimbal yang akan dilakukan esok dijauhkan dari gangguan jin dan setan yang bisa mengacaukan jalannya ruwatan.

Setelah prosesi caos dahar, ritual kembali dilakukan di pertapaan Mandalasari Gua Semar. Dalam semedinya Mbah Rusmanto mendapat

${ }^{12}$ Adapun tempat-tempat yang didatangi dengan napak tilas dimulai dari Gunung Bismo, Gunung Pakuwaja, Gunung Kendil, Gunung Prahu, kemudian Tuk Bimalukar, Siti Hinggil, dan diakhiri di Kompleks Pertapaan Mandala Sari.

13 Kyai Kolo Dete pendiri Wonosobo itu disebut-sebut juga berambut gembel. http://www.suaramerdeka.com/harian/0609/05/ked08.htm. 
bisikan dari Kyai Kusmoyo atau Semar Bodronoyo bahwa nanti malam rohnya akan datang mengunjungi pertemuan kelompok penghayat Tunggul Sabtujati. Dalam dunia pewayangan, Semar dianggap sebagai dewa sakti yang menjelma sebagai rakyat jelata dengan mengemban misi untuk memberi nasehat dan mengayomi umat manusia.

Sebelum prosesi pemotongan rambut gembel dilaksanakan, terlebih dahulu para anak-anak berambut gembel diarak menuju Gua Semar. Beberapa ranjang berisi syarat permintaan anak berambut gembel juga turut diarak. Di antaranya adalah daging sapi goreng, daging ayam goreng, mie instan, telur puyuh, beberapa ekor ayam dan bebek yang masih hidup. Demikian juga sesajenan seperti tumpeng robyong, tumpeng kalung, dan unjukan jangkep dibawa untuk disajikan kepada leluhur mistis sebagai simbol bakti anak cucu yang mendiami dataran tinggi Dieng.

Anak-anak berambut gembel dan semua pernak pernik yang melekat pada sesajenan dibawa menuju telaga warna. Sampai di telaga warna, anakanak tersebut digendong orang tua masing-masing menuju pelataran pertapaan Mandalasari Gua Semar. ${ }^{14}$ Di pelataran Gua Semar inilah anak-anak berambut gembel dipotong rambutnya oleh orang-orang yang dipercaya memiliki kemampuan spiritual secara bergantian. Warga dataran tinggi Dieng meyakini bahwa setelah anak-anak diruwat, rambut gembel itu tidak akan tumbuh lagi. Namun apabila permintaan anak tidak dituruti rambut gembel diyakini akan tumbuh kembali.

Selesai prosesi potong rambut, potongan-potongan rambut gembel itu dibawa menuju Telaga Warna. ${ }^{15}$ Mbah Rusmanto sebagi pemimpin ritual mengadakan ritual kecil sebagai bentuk laporan kepada leluhur mistis bahwa upacara ruwatan telah usai dilaksanakan. Potongan rambut anak gembel

14 Gua semar panjangnya sekitar 4 meter dengan dinding batu dan dapat digunakan untuk bermeditasi. Ada gua lain di sampingnya yaitu gua Sumur dan Gua Jaran. Di dalam gua Sumur ini terdapat sumber air suci yang disebut "Tirta Prawitasari" di lokasi inilah umat Hindu biasanya mengadakan upacara ritual yang disebut Muspe/Mubakti.

15 Dinamakan telaga warna karena telaga tersebut memantulkan aneka warna yang indah. Disampingya terdapat telaga pengilon (telaga cermin) karena berkilau seperti cermin. Fenomena ini mungkin disebabkan oleh kandungan mineral telaga tersebut. Memang telaga-telaga tersebut terletak tidak jauh dari beberapa kawah yang mengeluarkan bahan-bahan mineral dari dalam bumi. Di sekitarnya terdapat beberapa gua kecil. 
yang dicukur inipun dilarung ke tengah telaga sebagai simbol dikembalikannya rambut gembel kepada sang penguasa laut selatan Nyai Roro Kidul.

Hasil analisis menunjukkan bahwa ruwat rambut gembel paling tidak dapat dikelompokkan ke dalam dua terma. Terma pertama menyebutkan bahwa ruwat rambut gembel merupakan ritual murni yang berangkat dari keyakinan masyarakat Dieng bahwa anak berambut gembel adalah anak istimewa, yang dengan keistimewaannya itu patut disyukuri dengan cara melaksanakan ruwat pada waktu rambutnya hendak di potong. Term ini juga menyisakan keyakinan yang cukup ekstrim bahwa anak berambut gembel adalah bentuk penjelman roh-roh gaib yang menitip pada anak yang menderita rambut gembel. Keyakinan seperti ini cukup masyhur di kalangan masyarakat dataran tinggi Dieng kendati tidak menjadi kepercayaan dominan.

Terma kedua menyebutkan bahwa rambut gembel adalah gejala patologis yang bersumber dari faktor genetik/keturunan. Sebagai bentuk penghormatan kepada para pendahulu, maka mereka warga Dieng melaksanakan satu bentuk ritual khas bernuansa lokal. Terma kedua ini menyisakan tradisi sebagian masyarakat dataran tinggi Dieng untuk tetap melaksanakan perayaan ruwat rambut gimbal, namun dibatasi terminologinya dalam syukuran keluarga. Melihat prosesi ruwat rambut gembel, dengan cara yang kedua ini, tidak ubahnya ketika kita menyaksikan syukuran khitan/sunat pada anak laki-laki bagi orang-orang kebanyakan. Seperti perlakuan istimewa kepada anak yang dikhitan atau dipotong rambutnya yang dapat diekspresikan dengan memberikan bingkisan atau uang kepada si anak.

Gesekan dua terma perdebatan ini telah menimbulkan satu bentuk reaksi yang justru berangkat dari luar, reaksi inilah yang kemudian disebut ekspansi pasar. Salah satu bentuk ekpansinya adalah beralihnya ritual rambut gembel dari ruwat personal keluarga menjadi ruwat publik, dengan pelibatan berbagai macam unsur termasuk di dalamnya unsur pemerintah dan sponsorship. Jika ruwat rambut gembel berangkat dari kepentingan personal keluarga, maka ruwatan bisa dipastikan waktu pelaksanaannya mengikuti kemauan si anak dan bersifat otonom. Sebaliknya jika mengikuti tren pasar, maka otonomi kapan si anak berambut gembel ingin diruwat, lambat laun akan hilang. Adanya legalisasi kebijakan pemerintah terhadap 
ruwat rambut gembel, secara tidak langsung bisa mengancam lestarinya budaya khas dataran tinggi Dieng. Pada konteks inilah dipandang perlu membedakan pariwisata dalam konteks fisik seperti panorama alam dengan pariwisata dalam konteks non fisik seperti bahasa, adat dan budaya. Sehingga dengan cara pandang yang berbeda juga maka mengekplorasikannya pun berbeda.

\section{F. Kesimpulan}

Unsur-unsur kebudayaan dalam masyarakat selalu mengalami perubahan. Intensitas perubahan itu sendiri tergantung pada dialektika yang terjadi dalam masyarakat dalam menyikapi perubahan. Dalam kasus masyarakat Dieng, tergambar secara nyata bahwa kepentingan ekonomilah yang menjadi pemicu utama dari pergeseran kebudayaan, hal itu sebagaimana tergambar dalam sikap mereka terhadap komodifikasi ritual rambut gimbal. Pergeseran nilai atau perubahan budaya itu dapat terjadi, terutama karena dipicu oleh proses kapitalisasi yang dilakukan oleh negara melalui pengembangan pasar pariwisata.

Secara teoretis studi ini memberi penjelasan bahwa religiusitas masyarakat menjadi sistem nilai yang mempengaruhi perilaku masyarakat untuk mengukuhkan moda produksi ekonomi yang berjalan, sekaligus mengawal perubahan sosial. Religiusitas masyarakat akan berubah, ketika moda produksi ekonomi mereka juga mulai berubah.[w] 


\section{BIBLIOGRAFI}

Cahyono, Bambang Tri, Masalah Petani Gurem, Yogyakarta: Liberty, 1983.

Darori, M. Amin, (ed.), Islam dan Kebudayaan Jawa, Yogyakarta: Gama Media, 2000.

Dinas Pariwisata Kabupaten Wonosobo, Perkembangan Jumlah Pariwisata Kabupaten Wonosobo, 2007.

Dokumen Stasiun TV SCTV, Potret, "Episode: Misteri Si Rambut Gimbal," Copy Right, 2006.

Dokumen BPPP Jawa Tengah, Sejarah Dieng, 2006.

Durkheim, Emile, The Elementery Forms of Religious Life, terj. Inyiak Ridwan, Yogyakarta: Ircisod, 2002.

Etzioni, Amitai, The Active Society, New York: The Free Press, 1968.

Faisal, Sanafiah, Format-format Penelitian Sosial, Jakarta: PT Radja Grafindo Persada, 1998.

Greeley, Anddrew M., Agama Suatu Teori Sekuler, Jakarta: Erlangga, 1982.

Hadi, Sutrisno, Metodologi Research, Yogyakarta: Fakultas Fsikologi UGM, 1995.

Hefner, Robert W., Geger Tengger Perubahan Sosial dan Perkelahian Politik Yogyakarta: LkiS, 1999.

Hoselitz, Bert, F., (ed.), Panduan Dasar Ilmu-ilmu Sosial Pemerkaya Pendekatan antar Disiplin, Jakarta: Rajawali Press, 1988.

Koentjaningrat, Metode-Metode Penelitan Masyarakat, Jakarta: Gramedia, 1990.

Laksono, P.M, dkk., Menjaga Alam Membela Masyarakat, Komunitas Lokal dan Pemanfaatan Mangrove di Teluk Bintuni, Yogyakarta: LAFALD Pustaka, 2000.

Li, Murray Tania, Proses Transformasi Daerah Pedalaman di Indonesia, Jakarta: Yayasan Obor Indonesia, 2002.

Merton, Robert K., Teori Sosial dan Teori Struktural, Jakarta: Rajawali, 1996.

Mulkhan, Abdul Munir, Islam Murni dalam Masyarakat Petani, Yogyakarta: Bentang, 2000. 
Nasr, Seyyed Hossein, Islam Agama, Sejarah dan Peradaban, Surabaya: Risalah Gusti, 2003.

Nazir, Muhammad, Metode Penelitian, Jakarta: Ghalia Indonesia, 1998.

Parson, Talcot, Esei-Esei Sosiologi, terj. S. Aji, Jakarta: Aksara Persada, 1986.

Peters, Jeroen, Kaum Tuo-Kaum Mudo, Perubahan Religius di Palembang 18211942, Jakarta: INIS, 1997.

Rahayu, Iin Tri dan Tristiadi Ardi Ardani, Obervasi dan Wawancara, Malang: Bayumedia Publishing, 2004.

Sudardi, Bani, dkk., "Potensi Tradisi Lisan Sebagai Sarana Meningkatkan Pariwisata Dataran Tinggi Jawa Tengah," Ringkasan Laporan Penelitian DP3M Dikti, 2009.

Salim, Agus, Teori dan Pradigma Penelitian Sosial, Yogyarkata: Tiara Wacana, 2002.

Sukatno, Otto, Dieng Poros Dunia, Yogyakarta: Ircisod, 2004.

Soemarjan, Selo, Sosiologi Suatu Pengantar, Jakarta: Rajawali Press, 1982.

Soproyogo, Imam dan Tobroni, Metodologi Penelitian Agama, Bandung: Remaja Rosda Karya, 1998.

\section{Internet:}

http://www.suaramerdeka.com/harian/0609/05/ked08.htm. Kyai Kolo Dete.

www. Kompas.com. "Wonosobo dan Banjarnegara Sepakat Selamtkan Dieng", edisi 2 Agustus 2002.

http://www.banjarnegarakab.go.id., "Obyek Wisata Di jalur Selatan Jateng: Dataran Tinggi Dieng Sangat Dikenal". Diakses dari Kedaulatan Rakyat Online Edisi Edisi 08 Juni 2009. 
